Tropical Journal of Pharmaceutical Research February 2020; 19 (2): 291-297

ISSN: $1596-5996$ (print); 1596-9827 (electronic) (C) Pharmacotherapy Group, Faculty of Pharmacy, University of Benin, Benin City, 300001 Nigeria.

\title{
Effect of polysaccharide from the root of Bupleurum Chinese DC and Bupleurum scorzonerifolium Willd on hydrogen peroxide-induced myocardial apoptosis
}

\author{
Jun-hui Gong, Xue-qing Liu*, Wei-li Ouyang, Hong-tao Zhu, Xiao-jun Ding, \\ Jian-feng Tang, Jian-feng Zhao, You-ming Zhang \\ Department of Cardiology, The People's Hospital of Danyang, Danyang 212300, Jiangsu, China
}

*For correspondence: Email: liuxqdy@163.com

Sent for review: 20 July 2019

Revised accepted: 27 January 2020

\begin{abstract}
Purpose: To investigate the protective effect of polysaccharide (BRP) from the root of Bupleurum Chinese DC. and Bupleurum scorzonerifolium Willd. on cardiomyocyte cells.

Methods: Response surface methodology (RSM) based on Box-Behnken Design (BBD) was performed to optimize the extraction conditions for BRP. The effect of BRP on cardiomyocyte cell apoptosis was evaluated in $\mathrm{H} 9 \mathrm{c} 2$ cells treated with hydrogen peroxide $\left(\mathrm{H}_{2} \mathrm{O}_{2}\right)$. Cell viability was determined by CCK-8 assay, while oxidative stress levels in H9c2 cells, including lactate dehydrogenase (LDH), superoxide dismutase (SOD), catalase (CAT) and creatine kinase (CK) were determined using commercial kits following the manufacture's instruction. mRNA expressions (caspase-3, caspase-8, caspase-9 and Fas) were determined by quantitative real time-polymerase chain reaction (RT-qPCR).

Results: The obtained optimal extraction conditions for BRP was as follows: extraction time (1.43 h), ratio of water to the raw material $(30 \mathrm{~mL} / \mathrm{g}$ ) and extraction times (2 times). BRP (200, 400, 600 and 800 $\mu \mathrm{g} / \mathrm{mL})$ significantly increased the cell viability of $\mathrm{H}_{2} \mathrm{O}_{2}$ induced $\mathrm{H} 9 \mathrm{c} 2$ cells $(p<0.05, p<0.01, p<0.01$, $p<0.01$, respectively). BRP (200, 400 and $800 \mu \mathrm{g} / \mathrm{mL}$ ) significantly decreased $L D H$ and CK levels $(p<$ $0.01, p<0.01, p<0.01$, respectively). However, BRP increased levels of SOD $(200,400$ and 800 $\mu \mathrm{g} / \mathrm{mL}, p<0.05)$ and CAT $(400$ and $800 \mu \mathrm{g} / \mathrm{mL}, p<0.05)$ in H9c2 cells. BRP significantly downregulated mRNA expressions of Caspase-3, Caspase-8, Caspase-9 and Fas (200, 400 and $800 \mu \mathrm{g} / \mathrm{mL}$, $p<0.01)$ in $\mathrm{H} 9 \mathrm{c} 2$ cells induced by $\mathrm{H} 2 \mathrm{O} 2$.

Conclusion: BRP protects cardiomyocyte against apoptosis via inhibition of oxidative stress and mitochondria-mediated intrinsic apoptosis, and thus, may be potential therapeutic agent for the management of cardiovascular diseases.
\end{abstract}

Keywords: Bupleurum Chinese, Bupleurum scorzonerifolium Willd., Polysaccharide, Cardiomyocyte, Apoptosis, H9c2 cell, Biochemical parameters

This is an Open Access article that uses a fund-ing model which does not charge readers or their institutions for access and distributed under the terms of the Creative Commons Attribution License (http://creativecommons.org/licenses/by/4.0) and the Budapest Open Access Initiative (http://www.budapestopenaccessinitiative.org/read), which permit unrestricted use, distribution, and reproduction in any medium, provided the original work is properly credited.

Tropical Journal of Pharmaceutical Research is indexed by Science Citation Index (SciSearch), Scopus, International Pharmaceutical Abstract, Chemical Abstracts, Embase, Index Copernicus, EBSCO, African Index Medicus, JournalSeek, Journal Citation Reports/Science Edition, Directory of Open Access Journals (DOAJ), African Journal Online, Bioline International, Open-J-Gate and Pharmacy Abstracts

\section{INTRODUCTION}

Incidence of cardiovascular disease is increasing every year, and myocardial infarction has become a leading cause of death worldwide [1]. Several studies have shown that oxidative stress, caused by several pathological factors, is the common mechanism underlying cardiovascular injury [2]. 
Bupleuri radix (BR) is the root of Bupleurum Chinese DC and Bupleurum scorzonerifolium Willd, and is used commonly in traditional Chinese medicine for the treatment of cold and fever, chest and hypochondriac pain and irregular menstruation [3]. Modern Pharmacology has demonstrated that BR possess antipyretic, analgesic, anti-inflammatory, anti-bacterial, enhancing immunity, anti-depression and anticancer effects and others [4]. Phytochemical studies have revealed the presence of saponins, volatile oils, polysaccharides, flavonoids, and sterols in BR [5].

It is well-known that polysaccharides are important biological macromolecules isolated from natural products [6]. polysaccharides derived from naturally occurring medicinal plants have been evaluated as drug candidates for treating various diseases due to their widespectrum of therapeutic activities, relative low toxicities, and minor side-effects $[7,8]$. However, no reports exist on the protective effect of Bupleuri Radix polysaccharide (BRP) on cardiomyocyte cells and its possible mechanisms of action on myocardial cell preservation. Therefore, we aimed to evaluate the protective effect of BRP on the $\mathrm{H}_{2} \mathrm{O}_{2}$-induced $\mathrm{H} 9 \mathrm{c} 2$ cell model.

\section{EXPERIMENTAL}

\section{Cells culture}

The cardiomyoblast $\mathrm{H} 9 \mathrm{c} 2$ cell line was obtained from Cell Bank of Chinese Academy of Sciences (Shanghai, China). The cells were cultured in 90 \% Dulbecco's modified Eagle's medium (DMEM) with $10 \%$ heat-inactivated fetal bovine serum (FBS) and antibiotics (1 \% penicillin and streptomycin). The cells were kept in a $37^{\circ} \mathrm{C}$ humidified incubator with $5 \% \mathrm{CO}_{2}$ and $95 \%$ air.

\section{Chemicals}

CCK-8, $\mathrm{H}_{2} \mathrm{O}_{2}$ and dimethyl sulfoxide (DMSO) were purchased from Sigma-Aldrich Co. (St. Louis, MO, USA). The DMEM media and FBS were obtained from Gibco Co. (Grand Island, NY, USA). The assay kits for lactate dehydrogenase $(\mathrm{LDH})$, superoxide dismutase (SOD), creatine kinase (CK) and catalase (CAT) were purchased from Nanjing Jiancheng Bioengineering Institute (Nanjing, China). RNA Trizol Reagent was purchased from Servicebio Company (Wuhan, China). The RevertAid First Strand cDNA Synthesis Kit was purchased from Thermo Fisher (MO, USA). All reagents and chemicals used in this study were of analytical grade.

\section{Preparation of BRP}

BRP was extracted as described earlier [8]. The dried Bupleuri Radix (BR) was processed to powder and exhaustively extracted with 95\% ethanol for $12 \mathrm{~h}$ to remove the colored materials, mono-saccharides, oligosaccharides and small molecule materials. After filtration, the residue was air dried and extracted with distilled water by reflux. The extract was left to cool at room temperature, filtered, and concentrated until it was reduced to one-tenth of the original volume. Then, ethanol was added slowly to reach a final concentration of $80 \%$. After leaving overnight at 4 ${ }^{\circ} \mathrm{C}$, the precipitate was collected by filtration. Then, it was washed thrice with pure ethanol and acetone and dried at $50{ }^{\circ} \mathrm{C}$ to obtain the crude BRP.

\section{Determination of BRP yield}

BRP content was determined by the phenolsulfuric method using D-glucose as standard reference. The percentage of polysaccharide yield (\%) was calculated as shown in Eq 1.

Yield $(\%)=W_{1} / W_{0}$

where $W_{1}$ was the content of crude polysaccharides and $W_{0}$ was the weight of dried Bupleuri radix used.

\section{Experimental design and statistical analysis}

Based on previous relevant single factor experimental results, three significant factors influencing BRP extraction, which include extraction time $(A)$, water to the raw material ratio (B), and extraction times (C) were confirmed. To obtain an optimal extraction of BRP, response surface methodology (RSM) based on BoxBehnken Design (BBD) was carried out in the present study. The three factors were designated as $A(1,1.5$ and $2 \mathrm{~h}), B(20,30$ and $40 \mathrm{~mL} / \mathrm{g}), C$ $(1,2$ and $3 n)$, and arranged into three levels $(-1$, 0 and 1). As shown in Table 1, seventeen experiments based on BBD with three centre points were performed in random order.

All tests were repeated three times, and the oneway analysis of variance (ANOVA) was used to analyse the BBD results. Design Expert (version 8.0.6, Stat-Ease, Inc., Minneapolis, MN, USA) software was used to estimate the response of independent variables. Response surfaces were drawn to determine the individual and interactive effects of the test variable on the response. Additional confirmatory experiments were 
conducted subsequently to verify the validity of the statistical experimental design.

\section{CCK-8 assay}

Cytotoxicity was evaluated using the CCK-8 assay. A $100 \mu \mathrm{L}$ cell suspension $\left(5 \times 10^{5}\right.$ cells $/ \mathrm{ml}$ ) was seeded in a 96 -well plate and incubated in an atmosphere of $5 \% \mathrm{CO}_{2} / 95 \%$ air at $37^{\circ} \mathrm{C}$ for $24 \mathrm{~h}$. BRP at varying concentrations $(50,100,200,400$, and $800 \mu \mathrm{g} / \mathrm{mL})$ was added to the cells and incubated for $24 \mathrm{~h}$ at $37^{\circ} \mathrm{C}$. The control cells were treated with $10 \mu \mathrm{L}$ of DMEM for $24 \mathrm{~h}$ at $37^{\circ} \mathrm{C}$. The cell viability $(n=4)$ in the CCK-8 assay was determined by measuring the absorbance (optical density, OD) at $450 \mathrm{~nm}$ using a microplate reader (Bio-Rad Laboratories, Inc., Hercules, CA, USA).

\section{Determination of LDH, CK, SOD and CAT in H9c2 cells}

Cells were inoculated into the 24-well plates for $24 \mathrm{~h}$. BRP at varying concentrations (200, 400 and $800 \mu \mathrm{g} / \mathrm{mL}$ ) was added to the cells and incubated for $24 \mathrm{~h}$ at $37^{\circ} \mathrm{C}$. Next, $\mathrm{H}_{2} \mathrm{O}_{2}$ at the final concentration of $100 \mu \mathrm{mol} / \mathrm{L}$ was added and cultured for $4 \mathrm{~h}$. After that, $\mathrm{H} 9 \mathrm{c} 2$ cell supernatants were collected, and the LDH, CK, SOD and CAT levels measured using the commercial kits following the manufacturer's instructions.

\section{Quantitative real time-polymerase chain reaction (RT-qPCR)}

H9c2 cell total RNA was extracted following the manufacturer's protocols, and the purity and concentration were determined by measuring the absorbance at 260 and $280 \mathrm{~nm}$. Next, $2 \mu \mathrm{g}$ of RNA was reverse transcribed into cDNA using the RevertAid First Strand cDNA synthesis kit. RT-qPCR was performed using an $A B I$ StepOnePlus system (Applied Biosystems, CA, USA). Reaction conditions for the RT-qPCR were as follows: $95^{\circ} \mathrm{C}$ for $30 \mathrm{~s}$, followed by cycles of $95^{\circ} \mathrm{C}$ for $5 \mathrm{~s}, 55^{\circ} \mathrm{C}$ for $30 \mathrm{~s}$, and $72{ }^{\circ} \mathrm{C}$ for $30 \mathrm{~s}$. And sequence of primers was showed in Table 2. The caspase- 3 , caspase- 8 , caspase- 9 , and Fas gene expression levels were normalised to $\beta$ actin and analysed using the $2^{-} \Delta \Delta^{\mathrm{CT}}$ method.

\section{Statistical analysis}

Data are presented as mean \pm standard deviation (SD) and group comparison was performed by ANOVA (SPSS 16.0, SPSS Inc., USA). $P<0.05$ was considered statistically significant.

Table 1: BBD experimental design with independent variables

\begin{tabular}{lcccc}
\hline Run & A & B & C & Yield (\%) \\
\hline 1 & 0.00 & 1.00 & -1.00 & 11.18 \\
2 & 0.00 & 0.00 & 0.00 & 12.22 \\
3 & 0.00 & -1.00 & 1.00 & 11.06 \\
4 & -1.00 & -1.00 & 0.00 & 11.51 \\
5 & 1.00 & 0.00 & 1.00 & 10.46 \\
6 & 0.00 & -1.00 & -1.00 & 11.43 \\
7 & 0.00 & 0.00 & 0.00 & 12.29 \\
8 & 1.00 & 0.00 & -1.00 & 11.53 \\
9 & 0.00 & 0.00 & 0.00 & 12.37 \\
10 & -1.00 & 0.00 & -1.00 & 11.48 \\
11 & 1.00 & -1.00 & 0.00 & 11.29 \\
12 & 1.00 & 1.00 & 0.00 & 11.17 \\
13 & 0.00 & 0.00 & 0.00 & 12.28 \\
14 & 0.00 & 0.00 & 0.00 & 12.11 \\
15 & -1.00 & 1.00 & 0.00 & 11.46 \\
16 & 0.00 & 1.00 & 1.00 & 10.59 \\
17 & -1.00 & 0.00 & 1.00 & 11.25 \\
\hline
\end{tabular}

$\mathrm{BBD}=$ Box-Behnken Design

Table 2: Sequence of primers

\begin{tabular}{|c|c|c|}
\hline $\begin{array}{l}\text { Gene } \\
\text { name }\end{array}$ & Forward primer & Reverse primer \\
\hline $\begin{array}{l}\beta \text {-actin } \\
\text { caspase-3 } \\
\text { caspase-9 } \\
\text { caspase-8 } \\
\text { Fas }\end{array}$ & $\begin{array}{l}\text { 5'-TTCCTACCCCCAATGTATCCG-3' } \\
\text { 5'- ACTGGAAAGCCGAAACTCTTCATCA -3' } \\
\text { 5'- AGCCAGATGCTGTCCCATACCA-3' } \\
\text { 5'-GATGAGGCAGACTTTCTGCT-3' } \\
\text { 5'-GTTGGAAAGAACCGAAGGACAA-3' }\end{array}$ & $\begin{array}{l}\text { 5'-CCACCCTGTTGCTGTAGCCATA-3' } \\
\text { 5'- GGAAGTCGGCCTCCACTGGTATC -3' } \\
\text { 5'- GGGAAGGTGGAGTAGGACACAAGG -3' } \\
\text { 5'-GATGAGGCAGACTTTCTGCT-3' } \\
\text { 5'-CCTCAAAGTAGGCACAGGATGT-3' }\end{array}$ \\
\hline
\end{tabular}




\section{RESULTS}

\section{Response surface analysis}

Using multiple regression analysis of the experimental data, the predicted response $Y$ for BRP (\%) extraction yield was obtained by the following second-order polynomial equation: Yield $=12.25-0.16 \mathrm{~A}-0.11 \mathrm{~B}-0.28 \mathrm{C}-0.018$ $A B-0.21 A C-0.055 B C-0.39 A^{2}-0.51 B^{2}$ $0.68 \mathrm{C}^{2}$. The F-test was used to test the statistical significance of the regression equation, and the effects of independent variables on the extraction yield were checked for adequacy and fitness by ANOVA.

The results from response surface analysis are shown in Table 3 and Figure 1 . The determination coefficient $\left(R^{2}\right)$ confirmed that the fitted model could explain $98.34 \%$ of the variations. The adjusted determination coefficient $\left(R^{2}\right.$ adj $\left.=0.9620\right)$ also indicated that the model was highly significant. In addition, it also showed a high degree of correlation between the observed and predicted values. A relatively low value of coefficient of variation $(\mathrm{CV}=2.71 \%)$ indicated a high degree of reliability and precision of the experimental values. The experiment had a very low $\mathrm{P}$-value $(P<0.0001)$ and a very high $F$-value $(F=42.13)$, suggesting that the proposed model was highly significant. In addition, F-value (2.10) and P-value (0.2425) lack-of-fit, showed no significance relative to the pure error, indicating that the model equation was adequate for predicting the BRP yield under any combination of variable values.

The 2D contour plots and 3D response surface are presented in Figure 1 and show the effects of independent variables and their mutual interaction on the BRP yield. The optimum conditions for the BRP yield were: an extraction temperature of $86.57^{\circ} \mathrm{C}$, an extraction time of $2.23 \mathrm{~h}$, and water to the raw material ratio of $10.77 \mathrm{~mL} / \mathrm{g}$. Therefore, the theoretically highest yield of BRP was predicted as $6.10 \%$ by the developed model. Verification experiments were carried out using the modified conditions, with an extraction temperature of $86.6^{\circ} \mathrm{C}$, an extraction time of $2.23 \mathrm{~h}$, and water to the raw material ratio of $10.8 \mathrm{~mL} / \mathrm{g}$ with three replicates. The average BRP yield from the actual experiments was $6.08 \%$, thus demonstrating the RSM model validity.
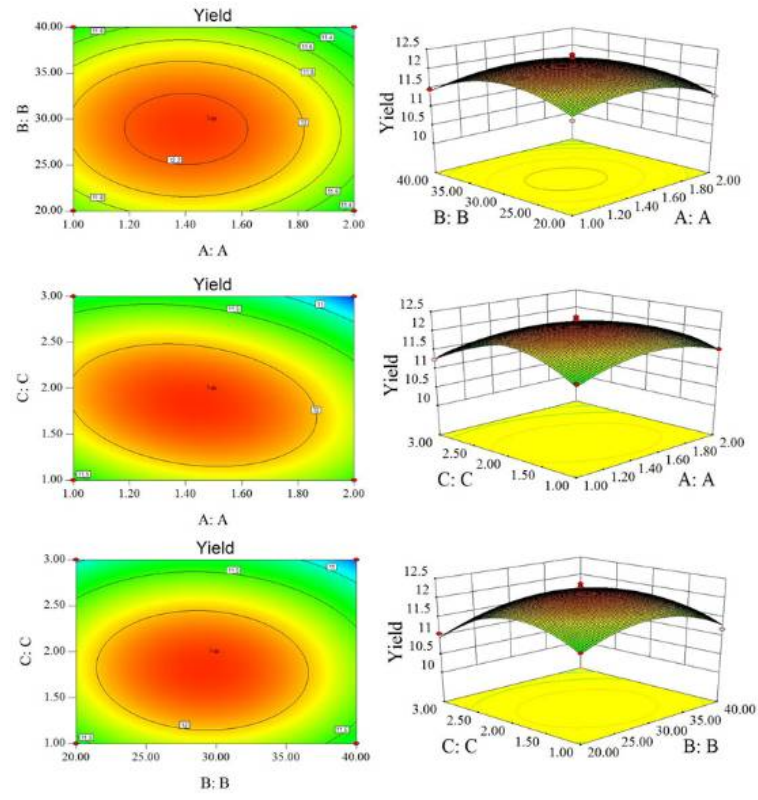

Figure 1: Results from response surface studies

Table 3: Analysis of variance (ANOVA) of experimental results from BBD

\begin{tabular}{|c|c|c|c|c|c|c|c|}
\hline Source & & Sum of squares & df & Mean square & & F -value & $P$-value \\
\hline Model & & 5.21 & 9 & 0.58 & & 42.13 & $<0.0001$ \\
\hline A & & 0.20 & 1 & 0.20 & & 14.21 & 0.0070 \\
\hline B & & 0.099 & 1 & 0.099 & & 7.21 & 0.0313 \\
\hline $\mathrm{C}$ & & 0.64 & 1 & 0.64 & & 46.46 & 0.0002 \\
\hline$A B$ & & $1.225^{\mathrm{t}-\mathrm{UU3}}$ & 1 & $1.225^{\mathrm{E}-\mathrm{UUS}}$ & & 0.089 & 0.7739 \\
\hline$A C$ & & 0.18 & 1 & 0.18 & & 12.84 & 0.0089 \\
\hline $\mathrm{BC}$ & & 0.012 & 1 & 0.012 & & 0.88 & 0.3793 \\
\hline$A^{2}$ & & 0.64 & 1 & 0.64 & & 46.78 & 0.0002 \\
\hline $\mathrm{B}^{2}$ & & 1.08 & 1 & 1.08 & & 78.37 & $<0.0001$ \\
\hline $\mathrm{C}^{2}$ & & 1.97 & 1 & 1.97 & & 143.03 & $<0.0001$ \\
\hline Residual & & 0.096 & 7 & 0.014 & & & \\
\hline Lack of Fit & & 0.059 & 3 & 0.020 & & 2.10 & 0.2425 \\
\hline Pure Error & & 0.037 & 4 & 9.330E-003 & & & \\
\hline Cor Total & & 5.31 & 16 & & & & \\
\hline $\begin{array}{l}\text { Standard } \\
\text { Deviation }\end{array}$ & Mean & C.V.\% & Press & $R^{2}$ & $R^{2}$ Adj & $\mathrm{R}^{2}$ Pred & $\begin{array}{l}\text { Adequate } \\
\text { precision }\end{array}$ \\
\hline 0.17 & 6.43 & 2.71 & 2.52 & 0.9834 & 0.9620 & 0.8030 & 19.187 \\
\hline
\end{tabular}

$\mathrm{BBD}=$ Box-Behnken Design. 


\section{CCK-8}

The results of the CCK- 8 assay are shown in Figure 2. $\mathrm{H} 9 \mathrm{c} 2$ cell viability decreased sharply after $\mathrm{H}_{2} \mathrm{O}_{2}$ induction $(100 \mu \mathrm{mo} 1 / \mathrm{L})$ for $4 \mathrm{~h}$, compared to normal $\mathrm{H} 9 \mathrm{c} 2$ cells $(p<0.01)$. However, the $\mathrm{H}_{2} \mathrm{O}_{2}$-induced $\mathrm{H} 9 \mathrm{c} 2$ cell viability increased significantly after BRP treatment $(200$, 400 , and $800 \mu \mathrm{g} / \mathrm{mL}$ ) when compared to the $\mathrm{H} 9 \mathrm{c} 2$ cells induced by $\mathrm{H}_{2} \mathrm{O}_{2}(p<0.05, p<0.01, p$ $<0.01$ and $p<0.01$, respectively). These results demonstrated that BRP could enhance the viability of $\mathrm{H}_{2} \mathrm{O}_{2}$ stimulated cardiomyocyte.

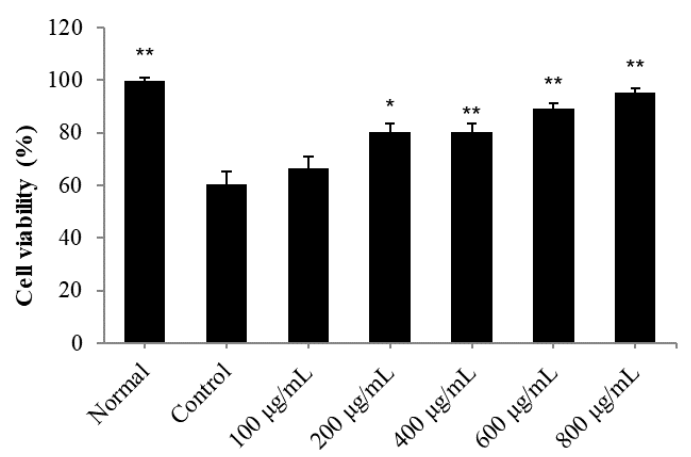

Figure 2: Effects of BRP on the cell viability rate of $\mathrm{H}_{2} \mathrm{O}_{2}$ stimulated $\mathrm{H} 9 \mathrm{c} 2$ cells. Data are expressed as mean $\pm \mathrm{SD}(\mathrm{n}=6) ;{ }^{*} p<0.05,{ }^{* *} p<0.01$, vs control group

\section{LDH and CK contents}

As shown in Figure 3, it could be seen that the $\mathrm{LDH}$ and CK contents in H9c2 cells induced by $\mathrm{H}_{2} \mathrm{O}_{2}$ increased $(p<0.01)$, compared to the normal cells. After treating with BRP (400 and $800 \mu \mathrm{g} / \mathrm{mL}$ ), LDH and CK levels significantly decreased ( $p<0.01$ and $p<0.01$, respectively), when compared to the control group. Above results indicated that BRP could reduce the levels of LDH and CK from the cytoplasm of cells induced with $\mathrm{H}_{2} \mathrm{O}_{2}$.
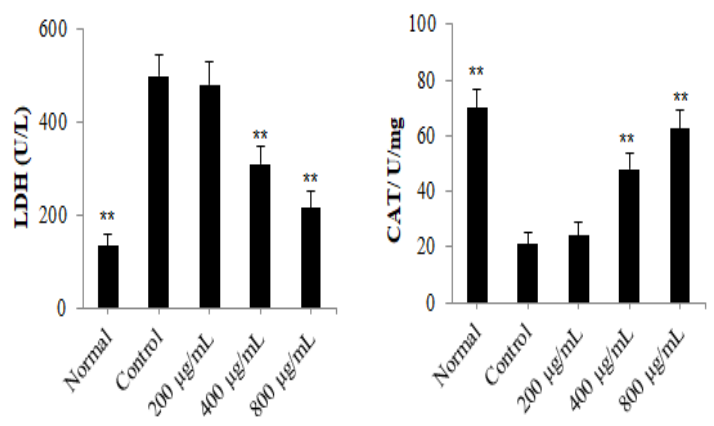

Figure 3: Effects of BRP on LDH and CK contents in $\mathrm{H}_{2} \mathrm{O}_{2}$-stimulated $\mathrm{H} 9 \mathrm{c} 2$ cells. Data are expressed as mean $\pm \mathrm{SD}(\mathrm{n}=6) ;{ }^{*} p<0.05,{ }^{* *} p<0.01$, vs control group

\section{SOD and CAT levels}

Effects of BRP on the SOD and CAT levels in H9c2 cells induced with $\mathrm{H}_{2} \mathrm{O}_{2}$ are presented in Figure 4. After $\mathrm{H}_{2} \mathrm{O}_{2}$ stimulation, levels of SOD and CAT in $\mathrm{H} 9 \mathrm{c} 2$ cells significantly decreased $(p$ $<0.01$ ) compared with normal H9c2 cells. And the SOD $(p<0.01$ and $p<0.01)$ and CAT $(p<$ 0.01 and $p<0.01$ ) levels in H9c2 cells treated with BRP (400 and $800 \mu \mathrm{g} / \mathrm{mL}$ ) were significantly increased, compared to the control group.
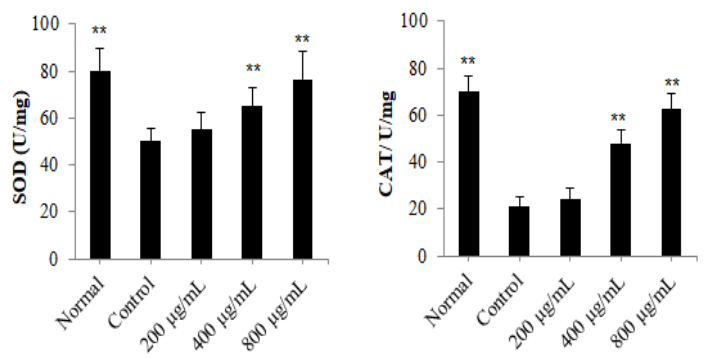

Figure 4: Effect of BRP on SOD and CAT contents in $\mathrm{H}_{2} \mathrm{O}_{2}$ stimulated $\mathrm{H} 9 \mathrm{c} 2$ cells. Data were expressed as mean $\pm \mathrm{SD}(\mathrm{n}=6) ;{ }^{*} p<0.05,{ }^{* \star} p<0.01$, vs control group

\section{RT-qPCR results}

As shown in Figure 5, the mRNA expressions of caspase-3, caspase-8, caspase- 9 , and Fas were up-regulated $(p<0.01)$ in the model cells. Compared to the model cells, the caspase-3, caspase-8, caspase-9, and Fas mRNA expressions decreased significantly in all BRPtreated $(200,400$, and $800 \mu \mathrm{g} / \mathrm{mL})$ cells.
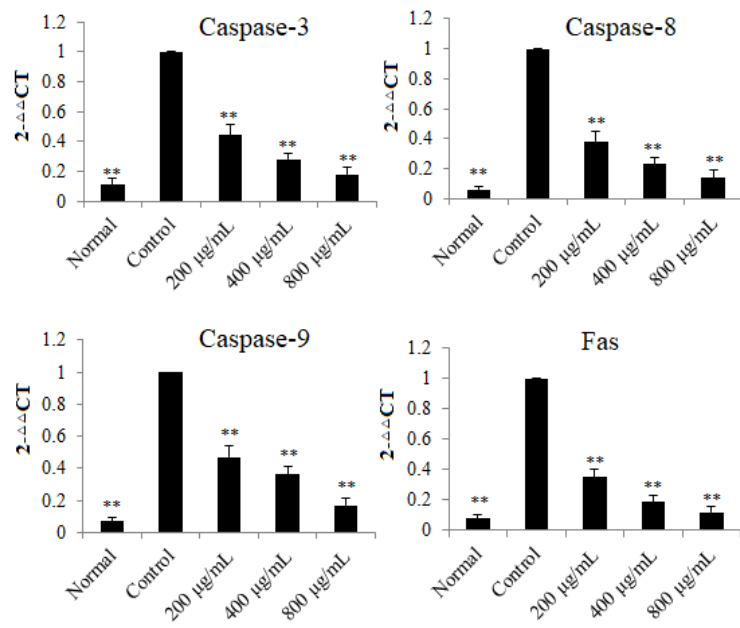

Figure 5: Effect of BRP on expressions of caspase-3, caspase-8, caspase- 9 and $\mathrm{Fas}$ in $\mathrm{H}_{2} \mathrm{O}_{2}$ stimulated $\mathrm{H} 9 \mathrm{c} 2$ cells. Data were expressed as mean $\pm \mathrm{SD}(\mathrm{n}=$ $6) ;{ }^{* \star} p<0.01$, vs control group 


\section{DISCUSSION}

Myocardial infarction could lead to myocardial ischemia and irreversible myocardial necrosis if not perfused timely with blood $[1,9]$. Myocardial ischemia is reported to occur due to an imbalance in the heart's oxygen supply and demand [10,11]. $\mathrm{H}_{2} \mathrm{O}_{2}$ may induce $\mathrm{ROS}$ generation in the mitochondria [11]. The myocardial apoptosis model of $\mathrm{H}_{2} \mathrm{O}_{2}$-induced $\mathrm{H} 9 \mathrm{c} 2$ cells is used routinely to study the underlying pathological processes and molecular mechanisms of myocardial ischemic injury $[11,12]$. The results of the present investigation showed that BRP could alleviate $\mathrm{H}_{2} \mathrm{O}_{2}$-induced myocardial apoptosis. In addition, BRP could also decrease CK and LDH levels in the cytoplasm.

CAT and SOD are critical anti-oxidative enzymes and generally regarded as the antioxidant defence system of the body that play a crucial role in suppressing oxidative stress [13]. The present results show that BRP increased levels of CAT and SOD, and inhibited the oxidative stress level in $\mathrm{H}_{2} \mathrm{O}_{2}$-induced $\mathrm{H} 9 \mathrm{c} 2$ cells. Caspase proteins, a group of aspartate specific cysteine proteases, play critical roles in regulating apoptosis induced by a variety of stimuli, such as oxidative stress, and caspase- 3 is the most important effector in the apoptotic process [14]. Caspase- 9 is the initial caspase in the caspase cascade reaction [15]. The combination of the death receptor Fas with the FasL ligand, initiates signal transduction and activation of caspase-8 and caspase-3 [16]. In the present study, we found that BRP down-regulated the mRNA expressions of caspase-3, caspase-8, caspase9 , and Fas, which demonstrate the protective effect of BRP on myocardial cell apoptosis.

\section{CONCLUSION}

The findings of the present investigation show that the polysaccharide from Bupleuri radix (BRP) alleviates myocardial apoptosis in $\mathrm{H} 9 \mathrm{c} 2$ cell induced with $\mathrm{H}_{2} \mathrm{O}_{2}$. The possible mechanism of action might be related to inhibition of oxidative stress and apoptosis. These findings may be useful in the development of novel medicine for the treatment of cardiovascular disease.

\section{DECLARATIONS}

\section{Conflict of interest}

No conflict of interest is associated with this work.

\section{Contribution of authors}

We declare that this work was done by the authors named in this article and all liabilities pertaining to claims relating to the content of this article will be borne by the authors.

\section{Open Access}

This is an Open Access article that uses a funding model which does not charge readers or their institutions for access and distributed under the terms of the Creative Commons Attribution License (http://creativecommons.org/licenses/by/ 4.0) and the Budapest Open Access Initiative (http://www.budapestopenaccessinitiative.org/rea d), which permit unrestricted use, distribution, and reproduction in any medium, provided the original work is properly credited.

\section{REFERENCES}

1. Reshma PL, Sainu NS, Mathew AK, Raghua KG. Mitochondrial dysfunction in $\mathrm{H} 9 \mathrm{c} 2$ cells during ischemia and amelioration with Tribulus terrestris L. Life Sci 2016; 152: $220-230$.

2. Halliwell B, Gutteridge JM. Free radicals in biology and medicine. Oxford: Clarendon Press, 1989. 121051p.

3. Chinese Pharmacopoeia Commission. Pharmacopoeia of the People's Republic of China Part I; Beijing: People's Medical Publishing House, 2015; p 280-281.

4. Xin G, Zhao XT, Huang XW. Research progress on chemical constituents and pharmacological effects of Bupleurum. Jilin Chin Med 2018; 38: 1196-1198.

5. Yan ML, Yang L, Hou AJ, Guo $X Y$, Man WJ, Xing XD, Han H. Research Progress on Chemical Composition and Pharmacological Effect of Bupleurum chinense. Inform on Tradit Chin Med 2018; 35: 103-109.

6. He X, Wang $X$, Fang J, Chang $Y$, Ning $N$, Guo H, Huang $L$, Huang $X$, Zhao Z. Structures, biological activities, and industrial applications of the polysaccharides from Hericium erinaceus (Lion's Mane) mushroom: A review. Int J Biol Macromol 2017; 97: 228-237.

7. Shang $H, L i R, W u H$, Sun Z. Polysaccharides from Trifolium repens $L$. extracted by different methods and extraction condition optimization. Sci Rep 2019; 9(1): 6353.

8. Hu MB, Peng W, Liu YJ, Wu N, Zhao CB, Xie DS, Yan D, Zhang XF, Tao XB, Wu CJ. Optimum Extraction of Polysaccharide from Areca Catechu Using Response Surface Methodology and Its Antioxidant Activity. J Food Process Pre 2017; 41: e12798.

9. Rezaee MA, Mohammadpour AH, Imenshahidi $M$, Mahmoudi $M$, Sankian $M$, Tsarouhas $K$, Tsakalof $A$, Tsatsakis AM, Moallem SA. Protective effect of erythropoietin on myocardial apoptosis in rats exposed to carbon monoxide. Life Sci 2016; 148:118-124. 
10. Zhang JW, Min DY, Zhou Y, Yang KC, Yu X, Chen DB. Protective effects of lycopene on $\mathrm{H} 2 \mathrm{O} 2$ induced oxidative stress in neonatal rat cardiomyocytes. Chin $\mathrm{J}$ Exp Trad Med Formul 2014; 20: 160-164.

11. Han MM, Wang WF, Liu MY, Li DS, Zhou B, Yu YH, Ren GP. FGF-21 protects H9c2 cardiomyoblasts against hydrogen peroxide induced oxidative stress injury. Acta Phrm Sin 2014; 49: 470-475.

12. Jovanović $S$, Ballantyne $T, D u Q$, Blagojević $M$, Jovanović A. Phenylephrine preconditioning in embryonic heart H9c2 cells is mediated by up-regulation of SUR2B/Kir6.2: A first evidence for functional role of SUR2B in sarcolemmal KATP channels and cardioprotection. Int J Biochem Cell Biol 2016; 70: 2328.
13. Xia J, Fang $Y$, Shi $Y$, Shen $X$, Wu J, Xie M, Li P, Pei $F$, $\mathrm{Hu} Q$. Effect of food matrices on the in vitro bioavailability and oxidative damage in PC12 cells of lead, Food Chem 2018; 266: 397-404.

14. Shan H, Yan R, Diao J, Lin L, Wang S, Zhang M, Zhang $R$, Wei J. Involvement of caspases and their upstream regulators in myocardial apoptosis in a rat model of selenium deficiency-induced dilated cardiomyopathy. $J$ Trace Elem Med Biol 2015; 31: 85-91.

15. Gao N, Budhraja A, Cheng S, Yao H, Zhang Z, Shi X. Induction of apoptosis in human leukemia cells by grape seed extract occurs via activation of c-Jun NH2-terminal kinase. Clin Cancer Res 2009; 15: 140-149.

16. Shen HM, Pervaiz S. Tnf receptor superfamily-induced cell death: redox-dependent execution. Faseb J Off Publ Feder Am Soc Exp Biol 2006; 20 (10): 1589. 